\title{
Analisa Dampak Bayangan Modul Terhadap Output PLTS
}

\author{
Adrian Mansur \\ PT PLN (Persero) UPDL Makassar \\ adrianmansur@gmail.com
}

\begin{abstract}
Solar cells are a technology that converts sunlight into electricity, therefore if there is a shadow that covers the surface of the module it will cause a decrease in energy production, therefore this study aims to see the impact of shadows on the module by analyzing the output per PLTS array, then the shadow source removed. The analysis shows that there is an increase in output at 06.00-12.00 in array 2 by $48 \%$ above the increase in average output which is only around 24\%, as well as in the output style that is not far adrift from other arrays with only $1 \%$ deviation remaining At 12.00-18.00 changes in output can also be observed in Array 4 by $46 \%$ above the average increase of only $39 \%$, as well as the output style with a deviation from $21 \%$ to $1 \%$.
\end{abstract}

Keywords: Solar cells, shadow, output, style

\begin{abstract}
ABSTRAK
Sel surya merupakan teknologi yang mengubah cahaya matahari menjadi listrik, oleh sebab itu jika terdapat bayangan yang menutupi permukaan modul maka akan menyebabkan penurunan produksi energi, oleh sebab itu penelitian ini bertujuan untuk melihat dampak bayangan pada modul dengan menganalisis output per array PLTS, selanjutnya sumber bayangan dihilangkan. Dari hasil analisa menunjukkan terdapat kenaikan output pada Pkl 06.00-12.00 pada array 2 sebesar 48\% diatas kenaikan output rata-rata yang hanya berkisar sebesar $24 \%$, demikian pula pada langgam output yang tidak terpaut jauh dari Array lainnya dengan deviasi yang tersisa hanya sebesar 1\%. Pada pukul 12.00-18.00 perubahan output juga dapat diamati pada Array 4 sebesar $46 \%$ diatas rata-rata kenaikan yang hanya sebesar $39 \%$, demikian pula dengan langgam output dengan deviasi dari $21 \%$ menjadi $1 \%$.
\end{abstract}

Kata kunci: Sel surya, bayangan, output, langgam 


\section{PENDAHULUAN}

Emisi rumah kaca dalam pemanfaatan energi fosil dalam produksi listrik mengalami peningkatan yang signifikan [1], oleh sebab itu energi Photovoltaic merupakan salah satu solusi yang banyak digunakan sebagai energi yang ramah lingkungan. Sel surya merupakan teknologi yang mengubah cahaya matahari langsung menjadi energi listrik dengan menggunakan efek photovoltaic yang memiliki karakterisitik seperti tegangan, arus dan tahanan ketika terpapar cahaya matahari [2] [3]. Secara umum penurunan efisiensi output panel PV meliputi permukaan modul yang kotor akibat debu, perubahan iradiasi, suhu tinggi dan bayangan [4] [5].

Jika terdapat bayangan yang kecil menutupi permukaan modul seperti akibat ranting pohon dan sumber bayangan lainnya, maka output daya dari modul akan mengalami penurunan yang siginifikan karena panel surya terdiri dari rangkaian sel surya yang dihubungkan secara seri[6][7]. Mengukur bayangan menjadi tantangan tersendiri karena sifat matahari yang bergerak sepanjang hari belum lagi bayangan yang mungkin juga ikut berubah akibat pengaruh lingkungan sekitar[7]. Terdapat solusi dalam mengatasi efek bayangan yakni dengan menggunakan diode bypass atau pengoptimalan daya, namun diode bypass belum sepenuhnya melindungi sel surya dari efek bayangan[8][9]. Strategi untuk mengurangi efek bayangan adalah dengan mengamati pola bayangan pada modul karena merupakan factor utama dalam kehilangan output daya PV [9].

Dalam sistem PLTS On grid, PV terhubung ke sistem jaringan listrik, yang pada siang hari listrik yang dihasilkan oleh PV dapat digunakan segera seperti untuk perkantoran, perumahan dan lain-lain, dapat pula dijual ke pemasok tenaga listrik yang terhubung[10]. Kapasitas PV sangat beragam mulai dari skala rumahan seperti rooftop hingga skala utility seperti $\mathrm{kW}$ dan MW. Beberapa penelitian menunjukkan penurunan produksi listrik proporsional terhadap efek bayangan dan penurunan radiasi matahari, hal ini berlaku jika diamatai per sel surya, namun pada tingkat modul dan array penurunan daya sering jauh dari linearitas dari efek bayangan[11]. Dalam sistem photovoltaic untuk mencapai output tegangan dan daya yang diinginkan, maka modul dihubungkan secara seri untuk membentuk string, selanjutnya string dihubungkan secara parallel untuk membentuk Array[12].

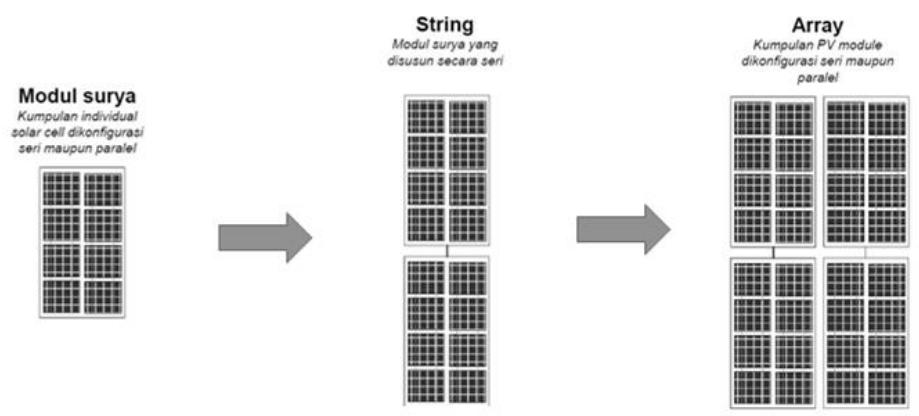

Gambar 1. Konfigurasi Modul Surya

\section{METODE/PERANCANGAN PENELITIAN}

Penilitian ini dilakukan pada PLTS On Grid 50 kWP PT PLN (Persero) UPDL Makassar

Penelitian ini menggunakan metode Island dan Trace dimana:

1. Metode diawali dengan membuat batas-batas (boundary) dari permasalahan yang berfokus pada output PLTS per Array. Selanjutnya dilakukan pengumpulan dan analisa output PLTS per Array.

2. Langkah berikutnya adalah, melakukan penelusuran (tracing) pencarian problem pada setiap Array sehingga dapat dilakukan perbaikan. 
3. Kemudian, apabila problem telah diketahui dan diisolasi, langkah berikutnya adalah menghitung nilai hilangnya produksi yang diakibatkan oleh problem tersebut

4. Tahap berikutnya adalah menghitung nilai dan menganalisis bentuk langgam output pasca perbaikan untuk masing-masing Array.

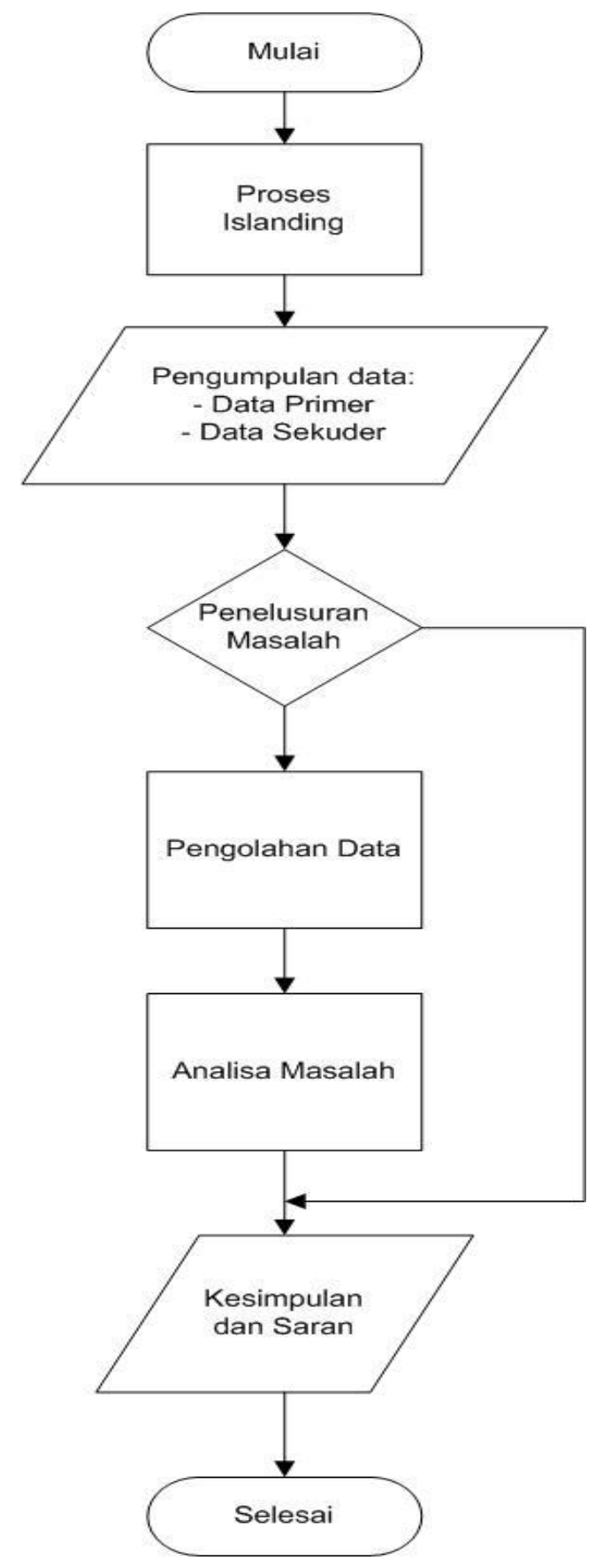

Gambar 2. Bagan alur pikir

Spesifikasi dan Konfigurasi Sistem PLTS On Grid UPDL Makassar Lokasi: PT PLN (Persero) UPDL Makassar

Latitude-Longitude: S 5¹3’23.67 ; E 119²9’40.40 
Tabel 1. Spesifikasi komponen utama PLTS

\begin{tabular}{|l|l|l|l|}
\hline No & Peralatan & Jumlah & Kapasitas \\
\hline 1 & Modul surya & 160 & $@ 315 \mathrm{Wp}$ \\
\hline 2 & Inverter & 5 & @ $10 \mathrm{kWp}$ \\
\hline 3 & Combiner Box & 5 & 2 input @ 10A \\
\hline
\end{tabular}

Tabel 2. Spesifikasi Array

\begin{tabular}{|l|l|}
\hline Total Series & 16 Seri \\
\hline Power Voltage & $585,6 \mathrm{~V}(16 \times 36,6 \mathrm{~V})$ \\
\hline Open Circuit Voltage & $721,6 \mathrm{~V}(16 \times 45,1 \mathrm{~V})$ \\
\hline Power Current & $8.61 \mathrm{~A}$ \\
\hline Short Circuit Current & $9,18 \mathrm{~A}$ \\
\hline Power Peak & $5,04 \mathrm{kWp}(16 \times 315 \mathrm{Wp})$ \\
\hline
\end{tabular}

Tabel 3. Spesifikasi Modul Surya

\begin{tabular}{|l|l|}
\hline Solar Cell Type & Poly-Crystalline \\
\hline Maximum Power (Pmax) & $315 \mathrm{Wp}$ \\
\hline Maximum Power Voltage (Vmp) & $36,6 \mathrm{~V}$ \\
\hline Maximum Power Current (Imp) & $8,61 \mathrm{~A}$ \\
\hline Open-Circuit Voltage (Voc) & $45,1 \mathrm{~V}$ \\
\hline Short-Circuit Current (Isc) & $9,18 \mathrm{~A}$ \\
\hline Modul Efficiency (\%) & $16,42 \%$ \\
\hline
\end{tabular}

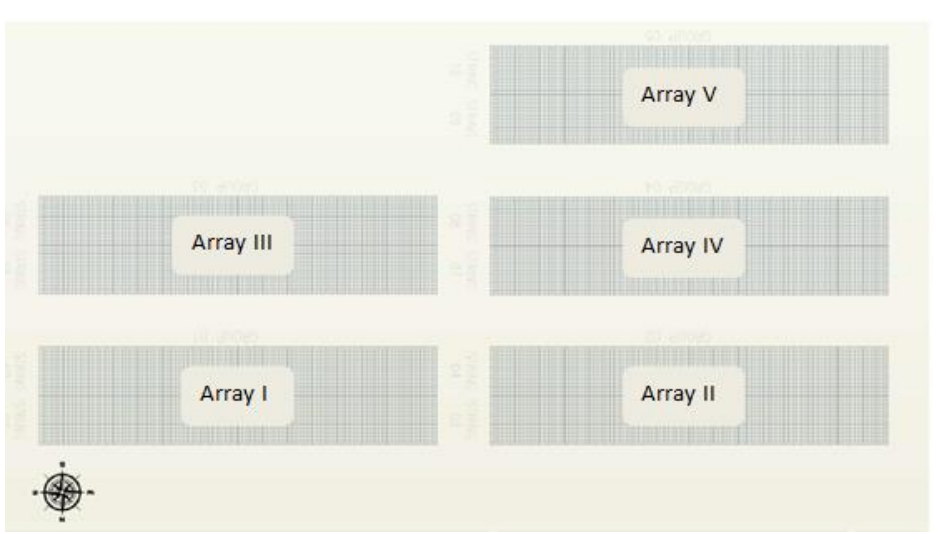

Gambar 3. Konfigurasi Array PLTS UPDL Makassar

Pertama-tama adalah dengan memetakan output dari setiap Array PLTS pada tanggal 06-15 Juli 2019, Diketahui bahwa output terkecil yakni array No 2 sedangkan output tertinggi pada array No 3, bentuk langgam output identik untuk setiap array dengan nilai terendah pada tanggal 09 Juli 2019 sesuai gambar 4 dibawah ini. 


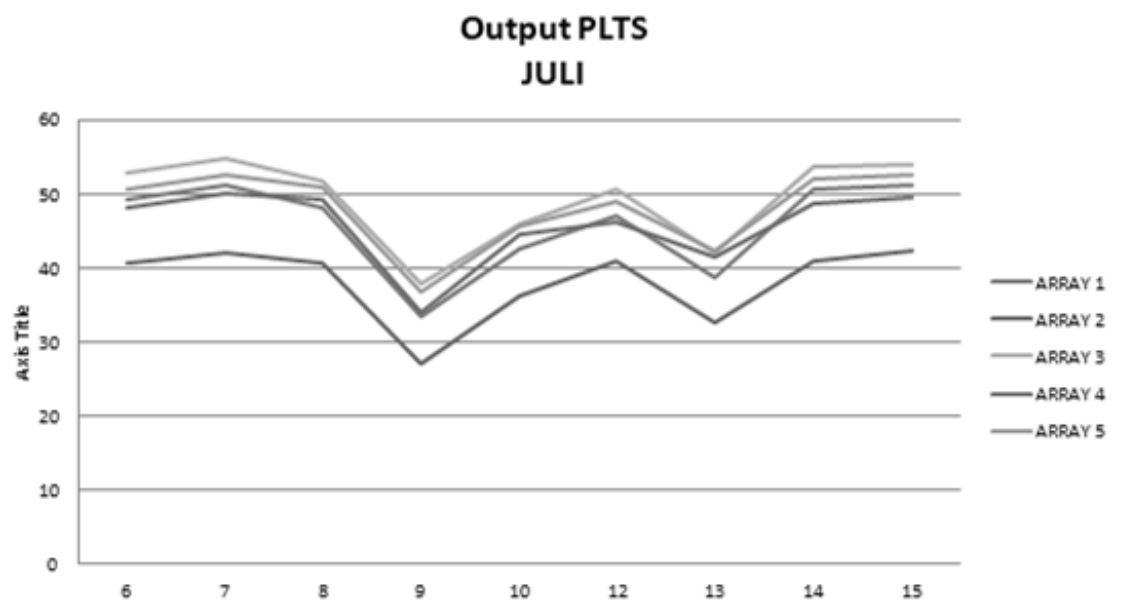

Gambar 4. langgam output 6-15 Juli 2019

Selanjutnya langgam output tanggal 09 Juli 2019 di breakdown dalam 2 bagian yakni pukul 06.0012.00 dan pukul 12.00-18.00, sehingga terlihat gambaran output untuk setiap bagian waktu untuk melihat dampak bayangan untuk setiap array pada rentang waktu tersebut.

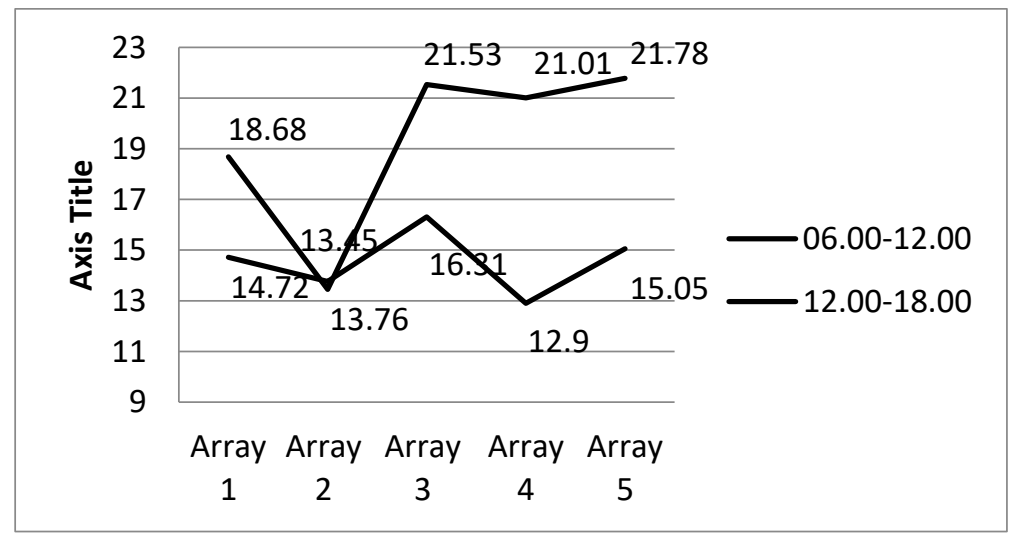

Gambar 5. Output Array PLTS tanggal 09 Juli 2019

Berdasarkan grafik diatas terlihat bahwa pada pukul 06.00-12.00 output terendah terjadi pada Array 2 yang disebabkan shading akibat pohon seperti yang terlihat pada gambar 6 dengan deviasi antara titik tertinggi dan terendah pada langgam sebesar 38\% disusul oleh Array 1 sebesar 14\% dan Array 4 sebesar $4 \%$ seperti yang ditunjukan pada gambar 7 . 


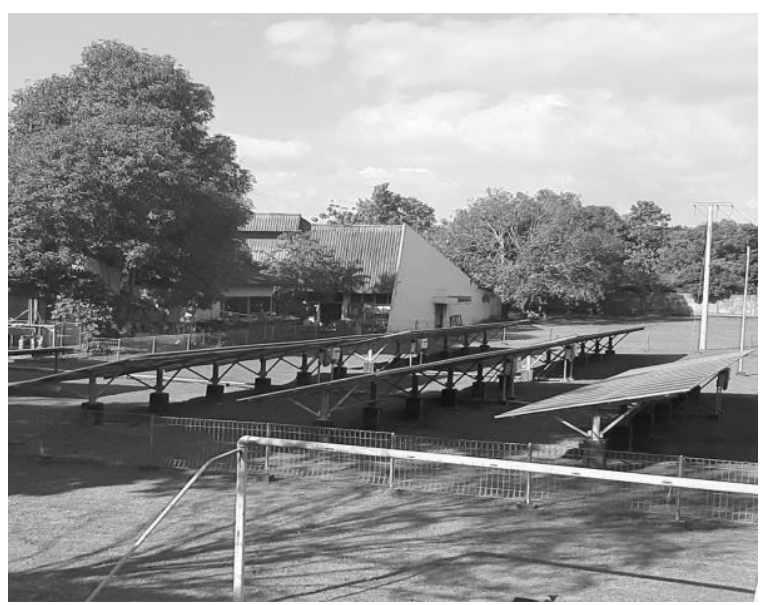

Gambar 6. Pohon Penyebab shading Pkl 06.00-12.00

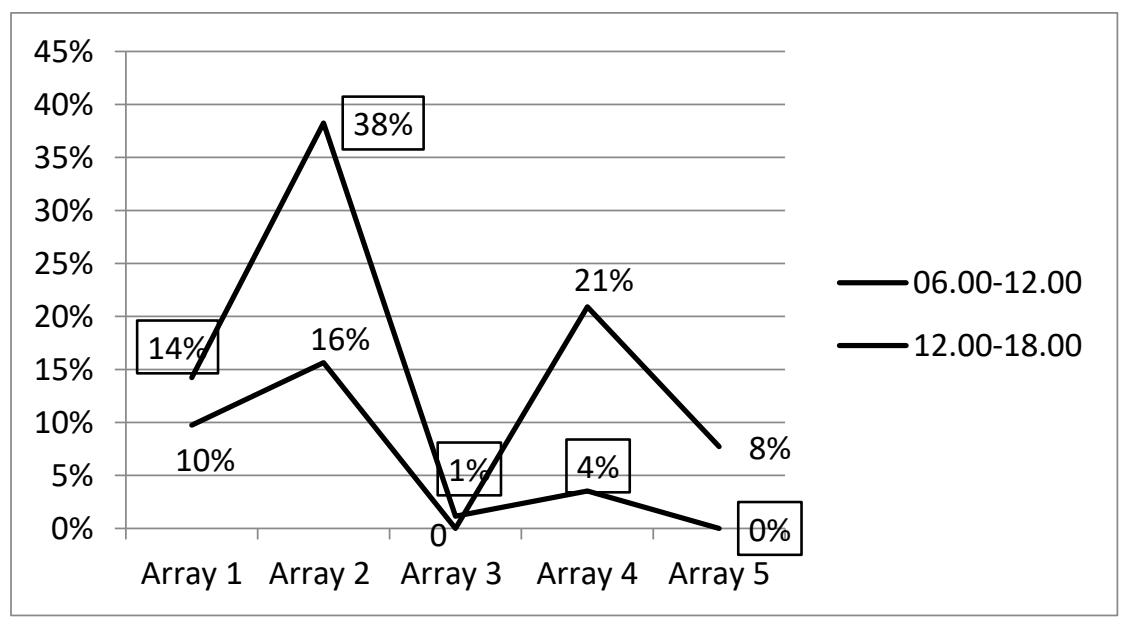

Gambar 7. Deviasi Output Array PLTS 09 Juli 2019

Pada pukul 12.00-18.00 terlihat deviasi output terendah terhadap titik tertinggi terjadi pada Array 4 sebesar 21\% disusul Array 2 Sebesar 16\% dan berurut Array 1 dan Array 5 sebesar 10\% dan $8 \%$ yang disebabkan oleh pohon seperti yang terlihat pada gambar 8 .

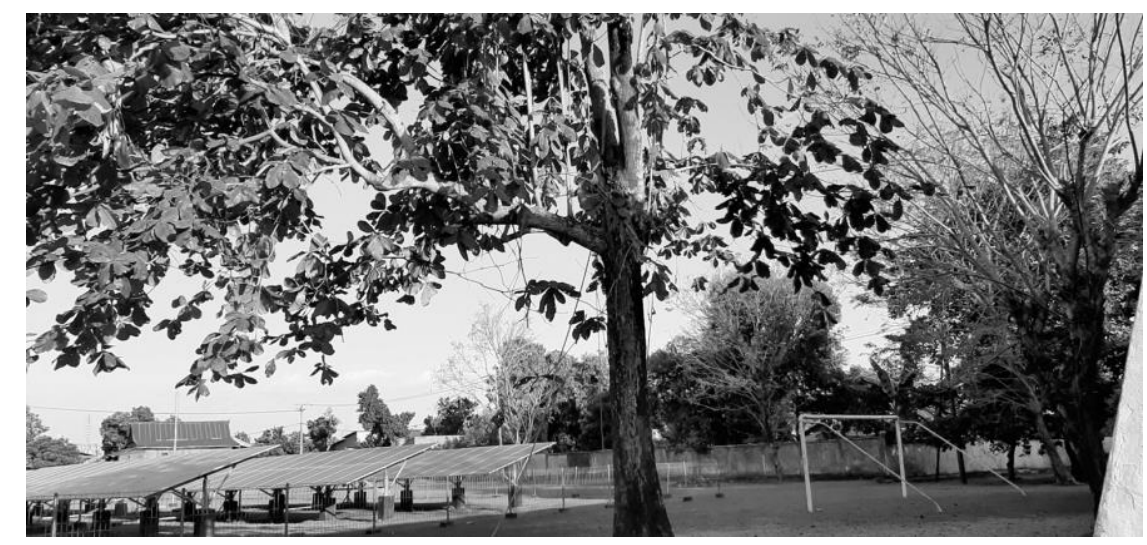

Gambar 8. Pohon penyebab shading Pkl 12.00-18.00

Selanjutnya penyebab shading dihilangkan dengan melakukan penebangan pohon seperti terlihat pada gambar 9 dibawah ini yang dilakukan pada tanggal 18 Juli 2019. 

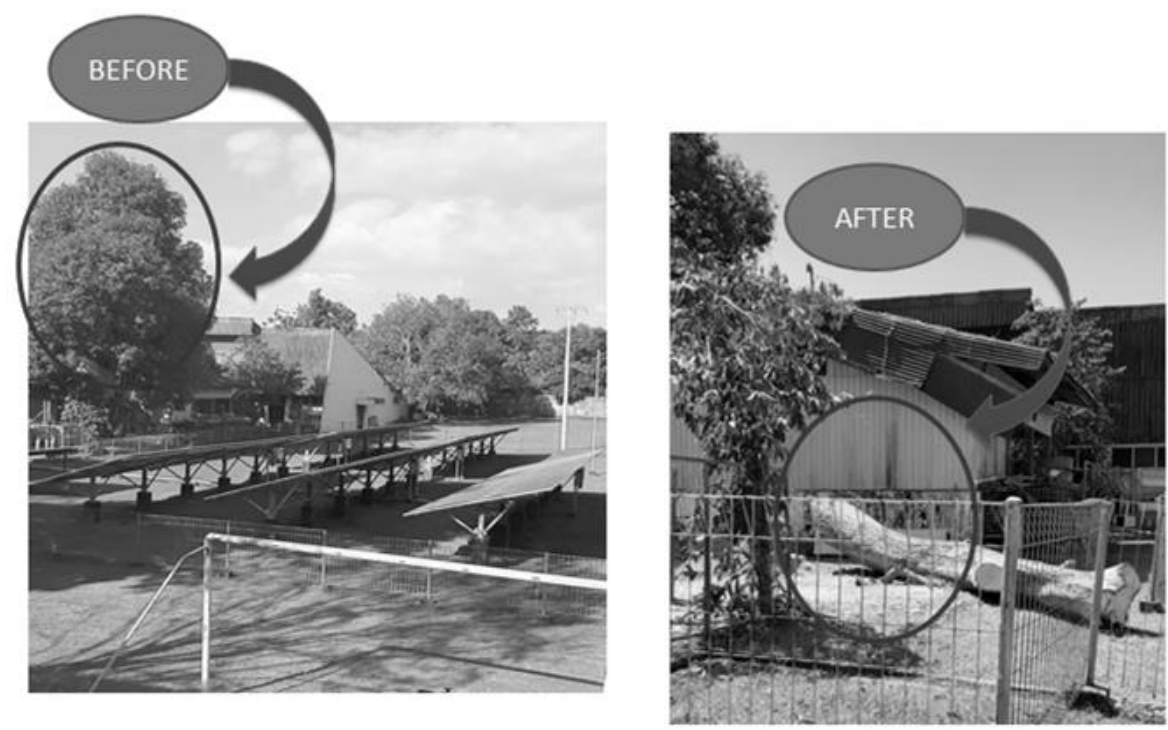

Gambar 9. Foto pohon penyebab sehading (before/After)

\section{HASIL DAN PEMBAHASAN}

Setelah dilakukan analisa penyebab dan tindak lanjut terhadap penyebab bayangan, selanjutnya dilakukan komparasi data tanggal 09 Juli 2019 dengan tanggal yang sama bulan berikutnya yakni 09 Agustus 2019. Pada gambar 10 persentase output PV terjadi kenaikan output setiap array pada PLTS, Pasca sumber bayangan telah dihilangkan terlihat pada pukul 06.00-12.00 kenaikan output terbesar terjadi pada Array 2 sebesar $48 \%$ disusul Array 1 sebesar $21 \%$ dan berurut Array 4, Array 3 dan Array 5 masing-masing sebesar 19\%, $16 \%$ dan $15 \%$. Sedangkan pukul 12.00-18.00 kenaikan output terbesar terjadi pada Array 4 sebesar 46\%, disusul array 2 sebesar 40\% dan berurut Array 1, Array 5 dan Array 3 sebesar $40 \%, 36 \%$ dan $34 \%$.

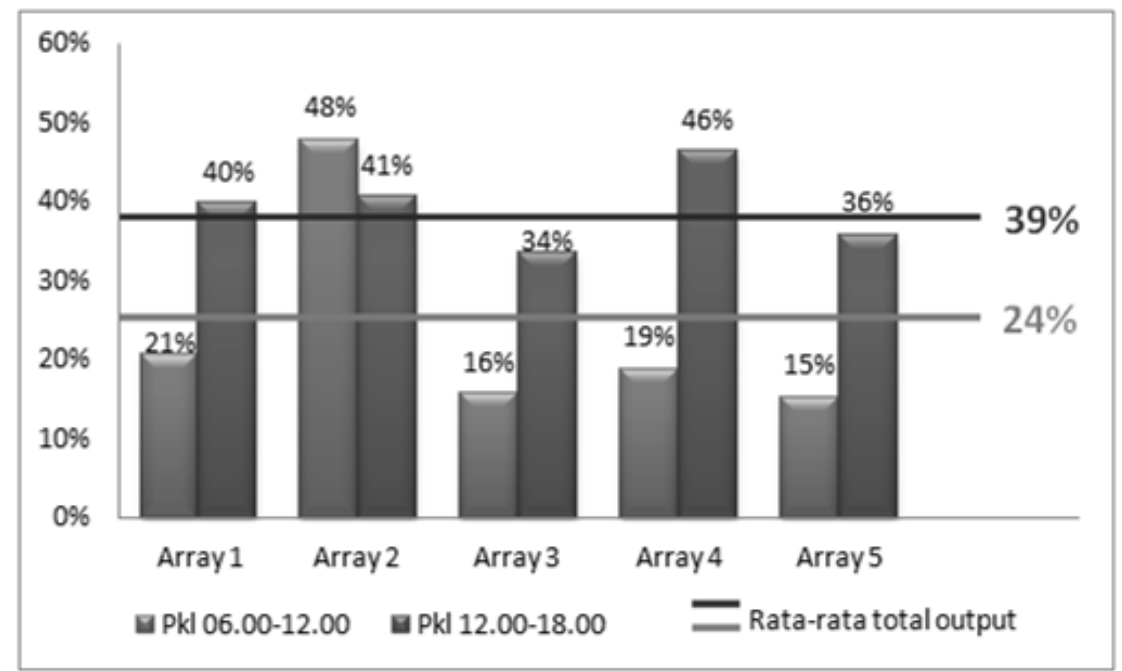

Gambar 10. Peresentase Output PV

Komparasi data tanggal 09 Juli dan 09 Agustus 2019 menunjukkan kenaikan produksi ratarata $24 \%$ pada pukul 06.00-12.00 terlihat bahwa hanya Array 2 yang berada jauh diatas kenaikan rata-rata yakni sebesar $48 \%$, nilai tersebut menunjukkan dampak dari sumber bayangan yang 
dihilangkan, hal ini dapat dibuktikan dengan perubahan langgam output setiap PV yang hampir sama antara Array sebagaimana yang terlihat pada gambar 11 dibawah ini.

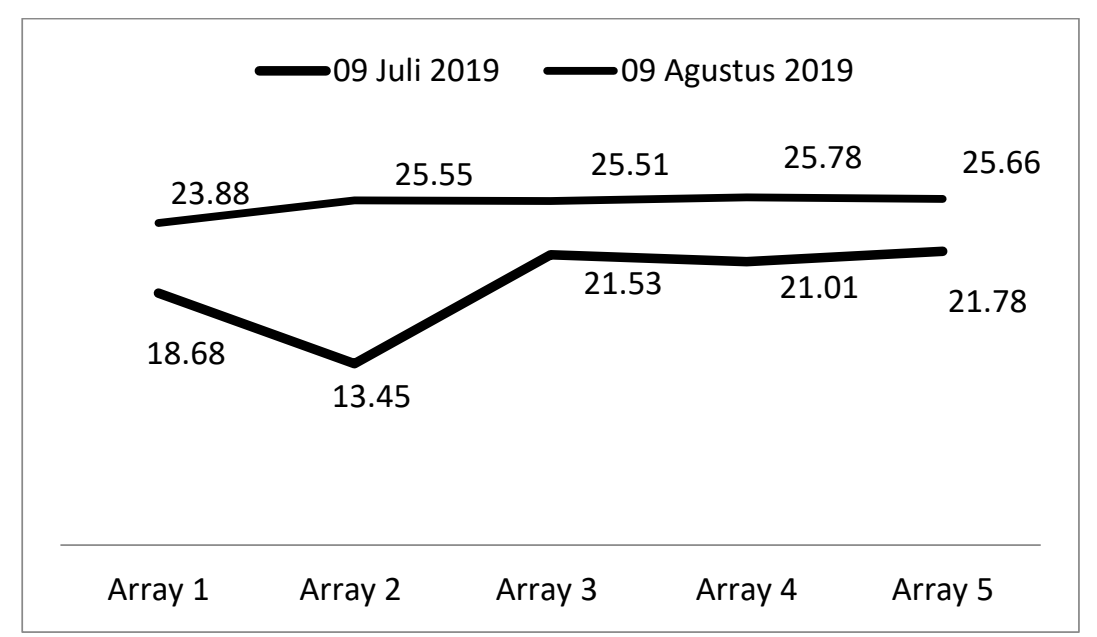

Gambar 11. Output PLTS Pkl 06.00-12.00

Sedangkan hasil komparasi pada pukul 12.00-18.00 menunjukkan kenaikan produksi rata-rata sebesar $39 \%$ nilai diatas rata-rata ditunjukkan secara berurut Array 4, Array 2 dan Array 1 sebesar $46 \%, 41 \%$ dan $40 \%$. Hal ini dapat pula terlihat pada perubahan langgam output yang hampir membentuk garis lurus seperti pada gambar 12 di bawah ini.

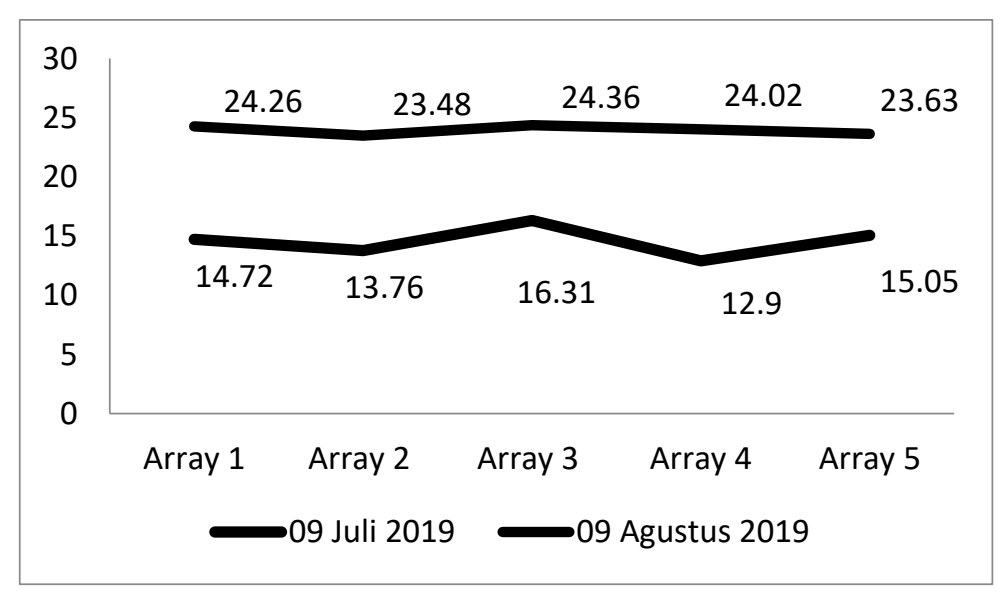

Gambar 12. Output PLTS Pkl 12.00-18.00

Pada pukul 06.00-12.00 Array 2 menunjukkan perbedaan deviasi yang signifikan yakni sebesar $38 \%$ menjadi $1 \%$ sedangkan Array 1 dari deviasi sebesar $14 \%$ menjadi $7 \%$ seperti yang ditunjukkan pada gambar 13. Meskipun Array 1 mengalami penurunan deviasi, namun masih cukup tinggi yang disebabkan oleh masih terdapat shading akibat gedung sebagaimana yang ditunjukkan pada gambar 14. 


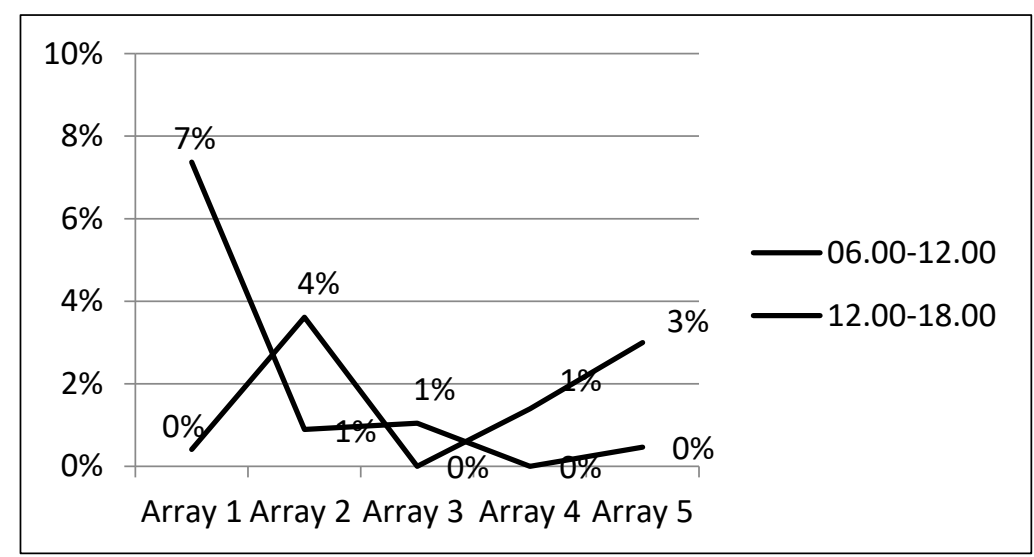

Gambar 13. Deviasi Output Array PV 09 Agustus 2019

Pada Pukul 12.00-18.00 deviasi tertinggi Array 4 sebesar 21\% menjadi 1\%, sedangkan Array 2 dari $16 \%$ menjadi sebesar 4\%, Array 1 dari 10\% menjadi $0 \%$ dan Array 5 dari 8\% menjadi 3\%. Perbedaan nilai langgam tersebut masih disebabkan oleh shading yang masih terdapat pada Array2, Array 4 dan Array 5 seperti pada gambar 14.
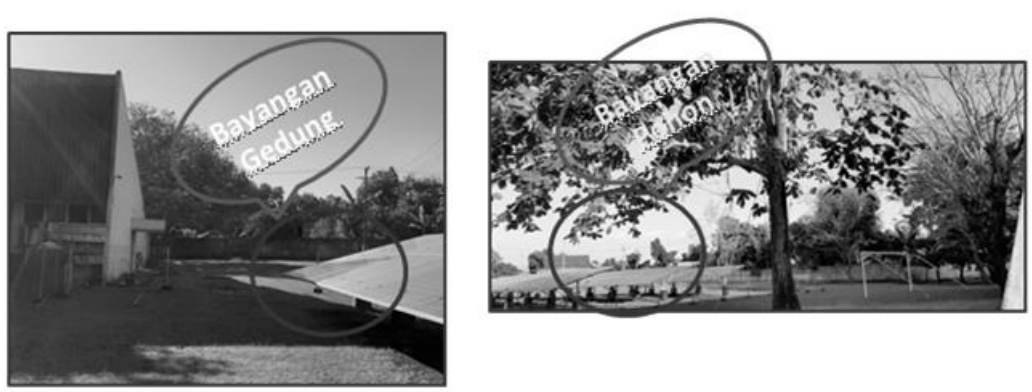

Gambar 14. Pohon penyebab bayangan pada pkl 12.00-18.00

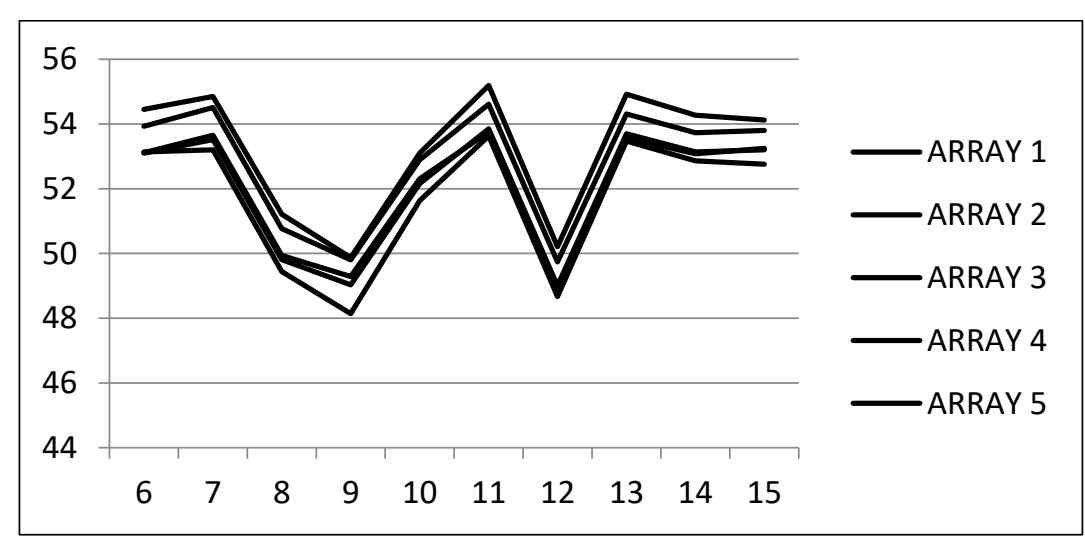

Gambar 15. Persentase Output PV

Berdasarkan gambar 15 terlihat bahwa nilai deviasi kumulatif tertinggi yakni Array 1 sebesar 7\%, Array 2 sebesar 5\%, Array 5 sebesar 3\% dan Array 3 dan 4 masing-masing sebesar 1\%. Jika dibandingkan langgam output PV tanggal 09 Agustus 2019 terlihat relevan dengan posisi nilai deviasi kumulatif tertinggi seperti ditunjukkan pada grafik diatas, dimana nilai terendah berurut pada Array 1, Array 2, Array 5, Array 3 dan 4. 


\section{KESIMPULAN DAN SARAN}

\subsection{Kesimpulan}

Setelah dilakukan pemeliharaan terhadap penyebab bayangan pada Array PLTS UPDL Makassar, terdapat kenaikan output pada Pkl 06.00-12.00 pada array 2 sebesar 48\% diatas kenaikan output rata-rata yang hanya berkisar sebesar $24 \%$, demikian pula pada langgam output yang tidak terpaut jauh dari Array lainnya dengan deviasi yang tersisa hanya sebesar 1\%. Pada pukul 12.0018.00 perubahan output juga dapat diamati pada Array 4 sebesar $46 \%$ diatas rata-rata kenaikan yang hanya sebesar 39\%, demikian pula dengan langgam output dengan deviasi dari $21 \%$ menjadi $1 \%$.

\subsection{Saran}

Dalam pembangunan PLTS perlu diperhatikan lokasi sekitar agar tidak terdapat penyebab bayangan yang bersifat permanen seperti gedung dan pohon disekitar lokasi.

\section{UCAPAN TERIMAKASIH}

Ucapan terima kasih kepada Seluruh karyawan PT PLN (Persero) UPDL Makassar atas bantuan dan kerjasama dalam menyelesaikan jurnal ini terkhusus bagian Laboratorium dan bagian Pelayanan.

\section{DAFTAR PUSTAKA}

[1] J. Walters, J. Kaminsky, and L. Gottschamer, "A systems analysis of factors influencing household solar PV adoption in Santiago, Chile,” Sustain., vol. 10, no. 4, pp. 1-17, 2018.

[2] R. Ramaraj, P. Pounraj, D. Prince Winston, J. S. Sakthi Suriya Raj, and S. Cynthia Christabel, "Analysis of PV power generation under partial shading and hotspot condition," Int. J. Appl. Eng. Res., vol. 10, no. 55, pp. 3443-3447, 2015.

[3] R. Hariharan, M. Chakkarapani, G. Saravana Ilango, and C. Nagamani, "A Method to Detect Photovoltaic Array Faults and Partial Shading in PV Systems," IEEE J. Photovoltaics, vol. 6, no. 5, pp. 1278-1285, 2016.

[4] K. A. K. Niazi, Y. Yang, M. Nasir, and D. Sera, "Evaluation of Interconnection Configuration Schemes for PV Modules with Switched-Inductor Converters under Partial Shading Conditions," Energies, vol. 12, no. 14, p. 2802, 2019.

[5] M. Al-Chaderchi, K. Sopian, T. Salameh, D. Zhang, and M. A. Alghoul, "Enhancing the performance of PV panel undergoing shading effects," Int. J. Power Electron. Drive Syst., vol. 9, no. 4, pp. 1937-1943, 2018.

[6] S. M. Salih and M. Q. Taha, "Analysis of Shading Impact Factor for Photovoltaic Modules Analysis of Shading Impact Factor for Photovoltaic Modules," no. July, 2017.

[7] P. Sathyanarayana, R. Ballal, P. S. Sagar, and G. Kumar, "Effect of shading on the performance of solar PV panel," Energy and Power, vol. 5, no. 1A, pp. 1-4, 2015.

[8] L. Davies, R. Thornton, P. Hudson, and B. Ray, "Automatic Detection and Characterization of Partial Shading in PV System," 2018 IEEE 7th World Conf. Photovolt. Energy Conversion, WCPEC 2018 - A Jt. Conf. 45th IEEE PVSC, 28th PVSEC 34th EU PVSEC, no. January, pp. 1185-1187, 2018.

[9] N. Djilali and N. Djilali, "PV array power output maximization under partial shading using new shifted PV array arrangements," Appl. Energy, vol. 187, no. September, pp. 326-337, 2017. 
[10] M. E. Meral and F. Diner, "A review of the factors affecting operation and efficiency of photovoltaic based electricity generation systems," Renew. Sustain. Energy Rev., vol. 15, no. 5, pp. 2176-2184, 2011.

[11] D. Sera and Y. Baghzouz, "On the impact of partial shading on PV output power," Int. Conf. Renew. Energy Sources, no. May, 2008.

[12] J. C. Teo, R. H. G. Tan, V. H. Mok, V. K. Ramachandaramurthy, and C. Tan, "Impact of partial shading on the P-V characteristics and the maximum power of a photovoltaic string," Energies, vol. 11, no. 7, 2018. 